\title{
Estimated live weight of growing Pêga breed donkeys
}

\author{
Camilla Garcia Moreira ${ }^{1}$ Júlio César de Carvalho Balieiro ${ }^{2}$ Madalena Lima Menezes $^{1}$ \\ Gabriela Ribeiro ${ }^{1}$ Olivia Carmen de Araújo Nascimento ${ }^{1}$ Roberta Ariboni Brandi ${ }^{*}$
}

'Departamento de Zootecnia, Faculdade de Zootecnia e Engenharia de Alimentos, Universidade de São Paulo (USP), Duque de Caxias Norte, 225, 13635-900, Pirassununga, SP, Brasil. E-mail: robertabrandi@usp.br. *Corresponding author.

${ }^{2}$ Departamento de Nutrição e Produção Animal, Faculdade de Medicina Veterinária e Zootecnia, Universidade de São Paulo (USP), Pirassununga, SP, Brasil.

\begin{abstract}
The equations available in the literature to estimate the body weight $(B W)$ of Pêga breed donkeys were evaluated using 25 animals aged 0-6 months and it was proposed an equation for BW prediction. For the measurement of the thoracic perimeter (TP) and for weighing the animals using the weighing tape, the animals were positioned in a forced station on a steep slope. An electronic scale was used for the determination of the BW. Accuracy of linear and nonlinear equations described in the literature was tested for BW prediction based on the animals' TP, followed by the comparison of these equations with the equation developed in the present study for BW prediction of Pêga breed donkeys. A difference was noted $(P<0.001)$ between the weights obtained on the electronic scale and the weighing tape. Linear and nonlinear equations available in the literature did not present favorable results with the data of the present study. The equation developed for the estimation of donkeys' $B W$ allowed the development of a weighing tape exclusive for young animals. Further evaluations are required for other Pêga donkey populations to confirm the efficacy of the proposed equation.

Key words: accuracy, asinine, equations, estimation, growth.
\end{abstract}

Estimativa de peso vivo de jumentos da raça Pêga em crescimento

RESUMO: O objetivo do presente estudo foi avaliar equações de estimativa de peso vivo (PV) disponíveis na literatura e propor uma equação para predição de PV de jumentos da raça Pêga, utilizando 25 animais do nascimento aos seis meses de idade. Para a mensuração do perímetro torácico (PT) e pesagem através da fita de peso, os animais foram posicionados em estação forçada. Uma balança eletrônica foi utilizada para determinar o PV. A acurácia de equações lineares e não lineares descritas na literatura foi testada para predição do PV, baseado no PT dos animais, e realizou-se comparações dessas equações com a equação desenvolvida no presente estudo para predição do PV dos jumentos Pêga. Houve diferença $(P<0,001)$ entre os pesos obtidos na balança e fica de peso. As equações lineares e não lineares disponíveis na literatura não apresentaram resultados favoráveis através dos dados obtidos no presente estudo. A equação desenvolvida para estimativa do PV dos jumentos permite o desenvolvimento de uma fita de peso exclusiva para animais jovens. Mais avaliações são necessárias in outras populações de jumentos da raça Pêga para confirmar a eficácia da equação proposta.

Palavras-chave: acurácia, asininos, crescimento, equações, estimativa.

\section{INTRODUCTION}

Considering the increasing appreciation of the Pêga donkeys, there is a rising need to refine their breeding methods (HOFFMANN et al., 2013). For this purpose, routine actions such as weighing animals using measuring tapes needs to be adapted for specific species and breed, as the existing tapes are personalized for horses (WAGNER \& TYLER, 2011) or donkeys of other breeds than Pêga (ELEY \& FRENCH, 1993; PEARSON \& OUASSAT, 1996; ALUJA et al., 2005).
Analysis of the body weight (BW) of an animal is necessary to monitor its weight development and to study drug application and diet formulation. Electronic scales, which are used for measuring BW, are usually not available at most farms (MARTINSON et al., 2014). In the absence of scales, the BW can be estimated by using weighing tapes or calculated through mathematical equations that use different morphometric evaluations (WAGNER \& TYLER, 2011; MARTINSON et al., 2014).

Equations for weight estimation for Mexican (ALUJA et al., 2005), Indian (PEARSON 
\& OUASSAT, 1996), and British breeds (ELEY \& FRENCH, 1993) were identified, but the differences in conformation among donkey breeds make these equations inefficient for other breeds (ALUJA et al., 2005). In addition, the available equations were developed for adult animals, which compromise their use in other life phases of animals (ALUJA et al., 2005; WAGNER \& TYLER, 2011; MARTINSON et al., 2014). For the Pêga donkeys, no citations were identified in the literature.

For adult donkeys, the formulas for weight prediction use body length (BL) and thoracic perimeter (TP) as independent variables (PEARSON \& OUASSAT, 1996); however ALUJA et al. (2005) suggested that equations formulated with TP alone better predicted the live weight of adult donkeys. The best adjustments of the prediction curves were reported to be linear (PEARSON \& OUASSAT, 1996; ALUJA et al., 2005).

The objective of the present study was to evaluate equations available in the literature that provide the estimates of live weight as well as to propose an equation for weight prediction for breeding Pêga donkeys.

\section{MATERIALS AND METHODS}

The study was conducted at the Atalla farm located in the city of Jaú, in the São Paulo state between January 2015 and March 2016. A total of 25 donkeys of both the gender of age 0-6 months were evaluated.

Animals were weighed monthly with the Líder B- $650^{\circledR}$ digital electronic scale of $1,000 \mathrm{~kg}$ capacity. The BW estimation was determined using a tape developed for equine species, and the TP measurement were performed by placing the tape just behind the withers, behind the shoulders, and by the girth (PIMENTEL et al., 2014). For this purpose, the animals were placed in forced station on concrete floor without slope.

Through the TP measurements, an equation was developed to predict the live weight of Pêga donkeys from birth to weaning age. Accuracy of the linear (MARCENAC et al., 1964; PEARSON \& OUASSAT, 1996; ALUJA et al., 2005; NENGOMASHA \& PEARSON, 2016) and nonlinear equations (Logistic, Gompertz, and Von Bertalanffy) described in the literature was also tested for BW prediction based on animals TP and the data obtained were compared with those obtained from using the proposed equation.

The experimental design used was subdivided plots, repeated several times over, with animals as the plot and the times of data collection as subplots. For the adjustment of linear models of first and second degrees as well as for the estimation of the parameters of interest, the method of maximum restricted likelihood was applied through the SAS program (version 9.4; SAS, 2010) using the procedure of PROC MIXED, with structure adjustment of unstructured errors. For the adjustment of the nonlinear models and for the estimation of the parameters, the minimum squares method was used through the SAS program (version 9.4) by using the PROC MODEL procedure, with adjustment of the independent error structure and by defining the Gauss Newton method as an iterative process. It was considered, adjusted to a set (xi; yi) of observed data, with $\mathrm{i}=1,2, \ldots, \mathrm{n}$, being $\alpha, \beta, \gamma$, and $\delta$, the parameters and $\epsilon i$ the errors according to each studied structure, the following nonlinear models:

Logistic: $y_{i}=\alpha /\left(1+\exp \left(\left(\beta-\gamma x_{i}\right)\right)\right)+\epsilon_{i}$ Gompertz: $y_{i}=\exp \left(\alpha-\exp \left(\beta+\gamma x_{i}\right)\right)+\epsilon_{i}$ Von Bertalanffy: $y_{i}=\alpha\left(1-\beta \exp \left(\gamma x_{i}\right)\right)^{3}+\epsilon_{i}$

For the evaluation of the different models studied, correlation and regression analyses were performed with the values predicted by the different models and the real BWs evaluated.

\section{RESULTS}

A difference $(\mathrm{P}<0.001)$ was noted between the mean weights obtained on the electronic scale and through the use of the weighing tape developed for equine species for donkeys of age 0-6 months (Table 1). The mean BW of the donkeys at birth as obtained on the scale was $47.60 \mathrm{~kg}$, which was $9.6 \%$ higher than that observed when the weighting tape for horses was used. At 6 months, young donkeys weigh an average of $119.52 \mathrm{~kg}$, which correspond to a value $3.6 \%$ higher than that observed with the tape, which indicates that the tape proposed for horses underestimates the weight of Pêga animals at their growth stage.

When compared with the average monthly weight obtained on the scale and through the use of the weighing tape for horses, it was observed that the weight obtained by the tape underestimates the average $\mathrm{BW}$ by $7.1 \%$.

To develop an equation to better adjust the BW prediction of young donkeys, an equation was developed using monthly TPs of animals from their birth to their weaning age (Table 2).

From the data obtained with the TP of growing donkeys (Table 2), an adjusted weight prediction equation was developed, which presented $\mathrm{R}^{2}$ of 0.9638 (Figure 1). 
Table 1 - Average live weight, estimated live weight measured with tape developed for horses, and relationship between the methodologies for weighing Pêga donkeys from birth to 6 months of age.

\begin{tabular}{lccc}
\hline Age (months) & Scale weight $(\mathrm{kg})$ & Tape weight $(\mathrm{kg})$ & Percent of the tape weight related to the scale weight $(\%)$ \\
\hline 0 & 47.6 & 43.0 & 90.3 \\
1 & 54.9 & 48.0 & 87.4 \\
2 & 72.7 & 66.6 & 91.6 \\
3 & 87.3 & 81.2 & 93.0 \\
4 & 101.3 & 96.1 & 94.9 \\
5 & 111.3 & 103.8 & 93.2 \\
6 & 119.5 & 115.2 & 96.4 \\
\hline
\end{tabular}

In the absence of any reference on tape weight estimation for young Pêga donkeys, TP values were applied to the equation drawn in this research and the estimated weights were calculated. This allowed the elaboration of a suggested specific weighing tape for the phase and breed, which increased the precision of the procedure of weight estimation by tape.

To verify the applicability of the existing equations in the literature, the TP database (Table 2) was applied to each of the literature equations. Regression analyzes were performed with the live weight values observed as a function of estimated BW by the different existing functions (Table 3). The generated equations have high $\mathrm{R}^{2}$, but this does not properly express the adjustment of the estimated weight with real weight. The equations closest to $\mathrm{Y}=0.00+1.00 \mathrm{X}$ are the most adequate ones to predict real live weight. In this context, it was verified that none of the equations cited in the literature present a good fit for the data of the present study (Table 3).

When testing the nonlinear equations present in the literature with data observed in this experiment, it was verified that the determination coefficient of the

Table 2 - Mean thoracic perimeter of growing donkeys evaluated from birth to 6 months of age.

\begin{tabular}{lc}
\hline Age (months) & Thoracic perimeter $(\mathrm{cm})$ \\
\hline 0 & 75.50 \\
1 & 81.82 \\
2 & 90.37 \\
3 & 98.05 \\
4 & 102.64 \\
5 & 106.34 \\
6 & 108.42 \\
\hline
\end{tabular}

connection equation was low (Table 4), suggesting the low applicability of nonlinear equations for animals of age up to 6 months.

\section{DISCUSSION}

This is a pioneer study regarding the prediction of the BW of young donkeys belonging to the Pêga breed. This species and breed are rapidly increasing in population in Brazil and; therefore, deserve special attention due to the lack of information on them for their better management.

The development of weighing tapes is very useful to field professionals and equine owners who do not have easy access to scales (HOFFMANN et al., 2013; MARTINSON et al., 2014). This research aimed to obtain and compare commercial weighing tapes developed for horses and equations to estimate the $\mathrm{BW}$ present in the literature, in addition to developing equations for predicting the BW of donkeys, for a specific life stage and breed, making it possible to make weighing tapes.

Commercially available weighing tapes do not cite the source or equation used in their development, which makes difficult to compare results obtained using them with the scientific data (WAGNER \& TYLER, 2011). In addition, as the tape was mostly developed for adult animals, it had low applicability for growing animals.

A difference was noted in the study of the young donkeys between the weights of the scale and of the weighing tape developed for horses. The weight of the tape represented $92.40 \%$ of the scale weight (Table 1), which corroborated with some previously reported results (WAGNER \& TYLER, 2011), who reported that the tape underestimates the actual weight of younger animals. Ellis and Hollands (1998) 


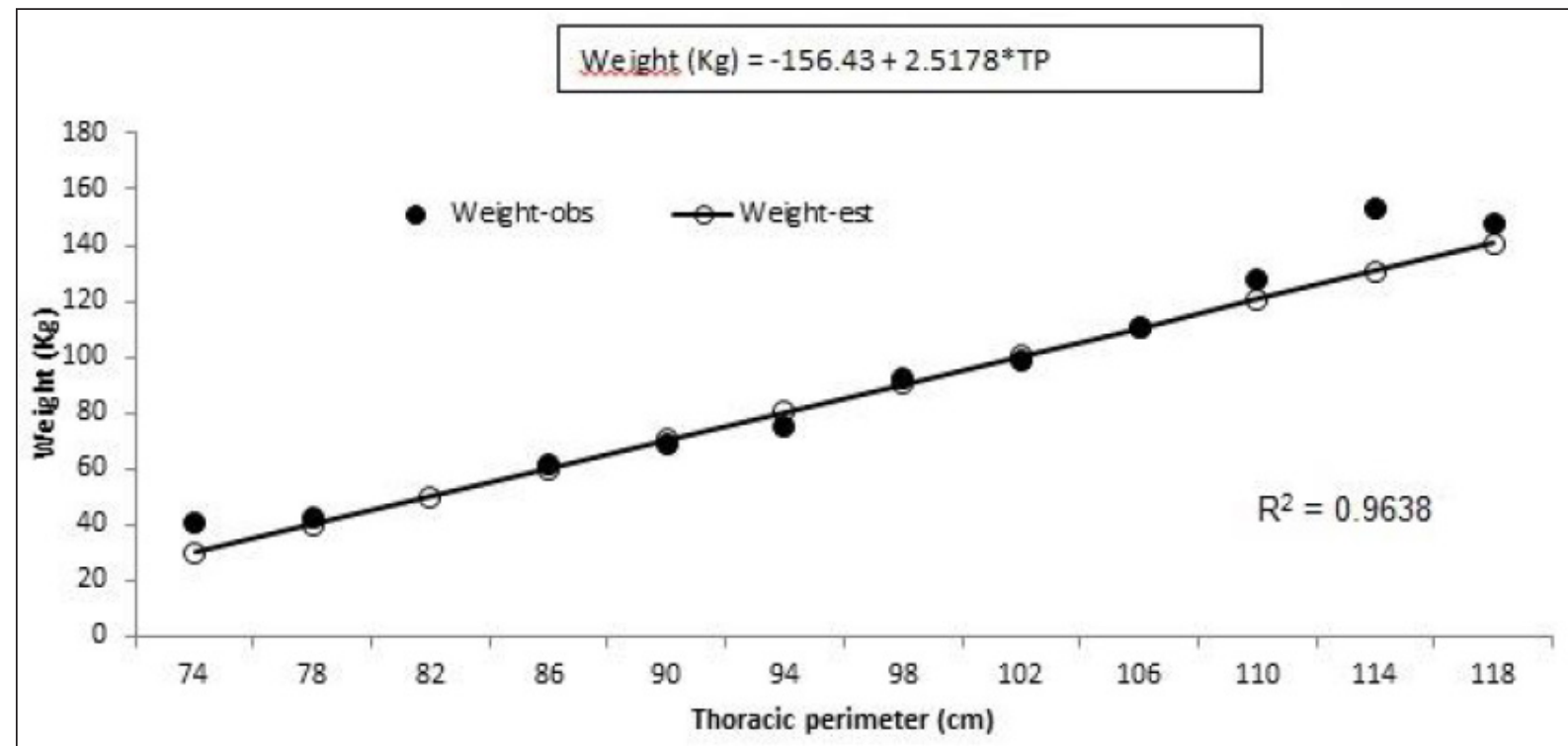

Figure 1 - Estimation of the live weight of growing donkeys developed according to the thoracic perimeter from birth to six month of age (created by Excel).

tested the accuracy of two brands of commercial tapes to estimate the weight of horses and observed divergence of results in weight estimation, which suggested the need for standardization of commercial measurement tapes. Divergence of results highlights the importance of methods elaboration for estimating live weight for each species and specific breeds. Considering the dissonance noted between the tape for horses and the scale, it can be further emphasized that there is an urgent need to develop an equation to predict the weight of Pêga donkeys of age 0-6 months (Figure 1).

When testing the equations referenced from the literature for the estimation of donkey weight, it was observed that the equation of weight estimation using the TP proposed in this research was more suitable for the subject species, as it showed higher determination coefficients (ALUJA et al., 2005) when compared with the use of more than one parameter, as previously described elsewhere (PEARSON \& OUASSAT, 1996) corroborating with the data obtained in this research.

Considering the equations developed for other breeds of donkeys (MARCENAC et al., 1964; PEARSON \& OUASSAT, 1996; ALUJA et al., 2005; NEGOMASHA, JELE, \& PEARSON, 1997), it was observed that those equations did not fit well when applied for the Pêga donkeys (Table 3), since they were developed for other breeds and for different life stages from the one used in the present research. In their

Table 3 - Regression equations of the live weight values observed as a function of the body weights estimated by the linear functions and respective determination coefficients.

\begin{tabular}{lcc}
\hline Method of weight estimation & $\begin{array}{c}\text { Regression equations of the body weight values observed } \\
\text { according to the estimated live weights }\end{array}$ & $\mathrm{R}^{2}$ \\
\hline Estimated weight & $\mathrm{Y}=0.1208+0.9983 \mathrm{X}$ & 0.96429 \\
Aluja et al. (2005) & $\mathrm{Y}=-49.208+1.605 \mathrm{X}$ & 0.96897 \\
Pearson e Ouassat (1996) & $\mathrm{Y}=-7.1793+1.0972 \mathrm{X}$ & 0.97083 \\
Nengomasha e Pearson (2016) & $\mathrm{Y}=25.0207+0.7571 \mathrm{X}$ & 0.96429 \\
Marcenac et al. (1964) & $\mathrm{Y}=3.565+1.11 \mathrm{X}$ & 0.97076 \\
\hline
\end{tabular}

*Estimated by the equation developed in the present study $[\mathrm{BW}(\mathrm{Kg})=-156.43+25178 * \mathrm{TP}]$; $\mathrm{BW}=$ body weight; $\mathrm{TP}=$ thoracic perimeter; $\mathrm{R}^{2}$ - determination coefficient. 
Table 4 - Regression equations of the live weight values observed as a function of the body weights estimated by the nonlinear functions and respective determination coefficients.

\begin{tabular}{lccc}
\hline \multirow{2}{*}{ Parameters } & & & \\
\cline { 2 - 4 } $\mathrm{R}^{2}$ & Logistic & Gompertz & Von Bertalanffy \\
\cline { 2 - 4 } Error & 0.65 & 0.6471 & 0.6427 \\
$\mathrm{~A}$ & 70 & 70 & 70 \\
$\mathrm{~B}$ & 127.4694 & 136.2692 & 161.7614 \\
$\mathrm{~K}$ & 0.901345 & 0.306415 & 0.793323 \\
\hline
\end{tabular}

R2 - coefficient of determination; A - asymptotic weight (weight/height of the animal at maturity); B - integration constant related to the initial weight/height of the animal; $\mathrm{K}$ - maturity rate (speed at which the animal approaches adulthood).

massive majority, the tapes are developed for adult animals and not applicable to the target phase in this study, favoring the divergence of the observed data.

The application of nonlinear equations did not converge with the data of this study to obtain the weight of the Pêga nursing donkeys. Low $\mathrm{R}^{2}$ for weight (Table 4) was observed using Logistic, Gompertz, and Von Bertalanffy curves and lower values of $\mathrm{R}^{2}$ $(0.9638)$ was observed in this research when a linear equation of first degree was applied for the prediction of the weight (Figure 1), which corroborates with that observed by JULLIAND \& MARTIN-ROSSET (2005). The nonlinear equations fit better when the animals are monitored for a long time until they reach adulthood, since they are used to describe the growth of the animal over a period of time, making possible to indirectly evaluate the genetic and environmental factors that influences growth as well as identifies the speed of growth (SARMENTO et al., 2016).

\section{CONCLUSION}

The equations available in the literature for donkeys do not fit well with those for nursing donkeys of the Pêga breed. When using weighing tape developed for equines, it is necessary to use a multiplicative correction factor of 1.0778-times the weight value obtained by using the tape. The equation of best fit for the estimation of nursing Pêga donkeys was the one developed in the present study [BW $(\mathrm{kg})$ $\left.=-156.43+2.5178^{*} \mathrm{TP}\right]$.

\section{BIOETHICS AND BIOSSECURITY COMMITTEE APPROVAL}

This study was approved by the Ethics Committee on the Animal Use of the College of Animal Science and Food
Engineering at the Universidade de São Paulo (protocol number: 2743200315).

\section{REFERENCES}

ALUJA, A.S. et al. Live weight estimation of donkeys in Central Mexico from measurement of thoracic circumference. Tropical Animal Health Production, v.37, suppl.1, p.159-171, 2005. Available from: <https://link.springer.com/article/10.1007/ s11250-005-9007-0>. Accessed: Apr. 6, 2016. doi: 10.1007/ s11250-005-9007-0.

ELEY, J.L.; FRENCH, J.M. Estimating the body weight of donkeys. Veterinary Record, v.132, p.249-251, 1993. Available from: <https://www.ncbi.nlm.nih.gov/pubmed/8460461>. Accessed: Apr. 6, 2016.

ELLIS, J.M.; HOLLANDS, T. Accuracy of different methods of estimating the weight of horses. Veterinary Record, v.143, p.335336, 1998. Available from: <http://veterinaryrecord.bmj.com>. Accessed: Jan. 6, 2016. doi: 10.1136/vr.143.12.335.

HOFFMANN, G. et al. Estimation of the body weight of Icelandic horses. Journal of Equine Veterinary Science, v.33, p.893-895, 2013. Available from: <http://www.sciencedirect.com/science/ article/pii/S0737080613000348>. Accessed: Jan. 15, 2015. doi: 10.1016/j.jevs.2013.01.002.

JULLIAND, V.; MARTIN-ROSSET, W. Growth and development in the equine. In: JULLIAND, V.; MARTIN-ROSSET, W. The growing horse: nutrition and prevention of growth disorders. Wageningen: Wageningen Academic Publishers, 2005. p.15-21.

MARCENAC, L.N. et al. Encyclopédie du cheval. Paris: Maloine, 1964. p. 1252.

MARTINSON, K.L. et al. Estimation of body weight and development of a body weight score for adult equids using morphometric measurements. Journal of Animal Science, v.92, p.2230-2238, 2014. Available from: <https://mc04. manuscriptcentral.com/cr-scielo>. Accessed: Apr. 8, 2016. doi:10.2527/jas2013-6689.

NENGOMASHA, E.M. et al. Morphological characteristics of working donkeys in south-western Zimbabwe. In: ATNESA 
Workshop: Improving Donkey Utilisation and Management. May 5-9, 1997, Debre Zeit, Ethiopia.

PEARSON, R.A.; OUASSAT, M. Estimation of the live weight and body condition of working donkeys in Morocco. Veterinary Record, v.138, p.229-233, 1996. Available from: <http:// europepmc.org/abstract/med/8686139>. Accessed: Apr. 6, 2016. doi: $10.1136 /$ vr.138.10.229.

PIMENTEL, M.M.L. et al. Biometric parameters of asinines (Equus asinus) used in evidence of race in the state Of Rio Grande do Norte. Acta Veterinaria Brasilica, v.8, n.2, p.136-143, 2014. Available from: <https://periodicos.ufersa.edu.br/index.php/acta/ article/view/3579>. Accessed: May 16, 2015. doi: 10.21708/ avb.2014.8.2.3579.
SARMENTO, J.L.R. et al. Analysis of the growth curve of Santa Ines sheep. Revista Brasileira de Zootecnia, v.35, p.435-442, 2016. Available from: $<$ https://scholar.googleusercontent.com/scholar? $\mathrm{q}=\mathrm{c}$ ache:PjFknG3VfSwJ:scholar.google.com/++Estudo+da+curva+de+ crescimento + de + ovinos + Santa + In $\%$ C3\%AAs. ++ Revista + Brasileira + de + Zootecnia, + v. 35, + p.435-442, $+2016 . \&$ hl=pt-BR\&as_sdt $=0,5>$. Accessed: May 10, 2016. doi: 10.1590/S1516-35982006000200014.

SAS Institute, S. SAS 9.4. Language Reference: concepts. Cary, 2010. p. 492.

WAGNER, E.L.; TYLER, P.J.A. Comparison of weight estimation methods in adult horses. Journal of Equine Veterinary Science, v.31, p.706-710, 2011. Available from: <www.j-evs.com>. Accessed: Apr. 6, 2016. doi: 10.1016/j.jevs.2011.05.002. 